
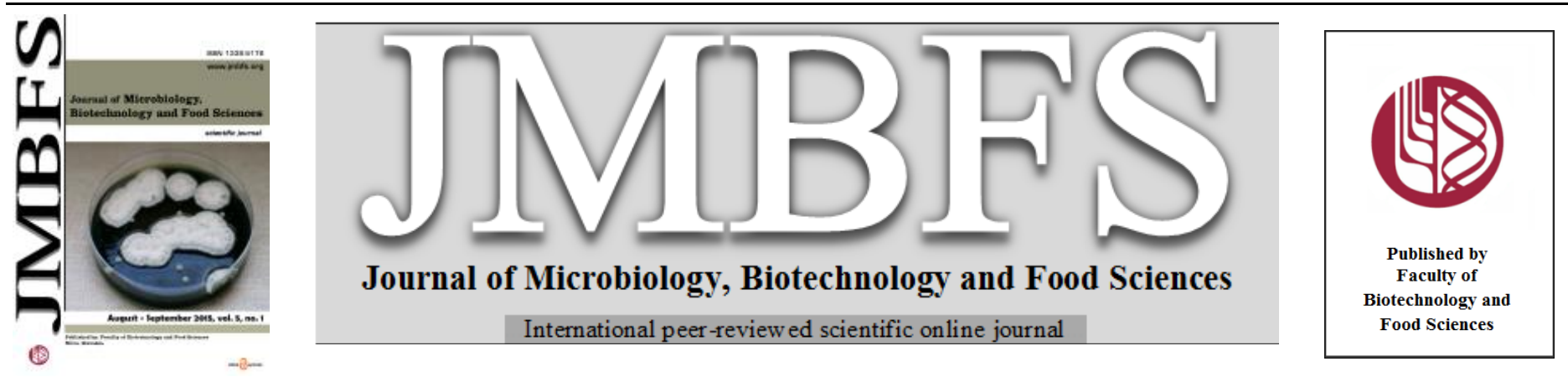

\title{
SCREENING, OPTIMIZATION AND CHARACTERIZATION OF EXTRACELLULAR LIPASE OF Aspergillus niger ATCC 1015
}

\section{Michael Bamitale Osho ${ }^{*}$ : Inyang Akpan ${ }^{2}$ and Olayinka Quadri Adio ${ }^{2}$}

Address(es): Dr. Michael Bamitale Osho,

${ }^{1}$ McPherson University, College of Natural and Applied Sciences, Department of Biological Sciences, Seriki Sotayo, P.M.B 2094,Abeokuta, Ogun State, Nigeria. $+2348032698955 ;+2347083887538$.

${ }^{2}$ Federal University of Agriculture, College of Biosciences, Department of Microbiology, P.M.B.2240, Abeokuta,Ogun State, Nigeria.

*Corresponding author: osho_michael@ rocketmail.com

doi: 10.15414/jmbfs.2015.5.1.40-44

ARTICLE INFO

Received 19. 9. 2014

Revised 15. 7. 2015

Accepted 16. 7. 2015

Published 1. 8. 2015

Regular article

open 2 access

\section{ABSTRACT}

This study focused on screening, production and characterization of strains of microorganisms isolated from groundnut cake wastes capable of producing lipolytic enzyme. Over one hundred isolates were screened on Bromocresol green medium to detect the presence of lipase producing organisms by a colour change of the medium from green to yellow around the colonies at pH $3.8-5.6$. Two of the isolates with NCBI Accession number ACJE01000015.1 and NT-166520.1 were identified as Aspergillus niger ATCC 1015 and A.niger CBS 513.88 respectively based on the nucleotide sequence of the domain of DNA gene. Other lipase producers include $A$. niger (B-05, B-17, B-33), A. oryzae (G -47, G- 51), and yeast, Candida sp. (H-06, H-11). Lipase activities of A. niger ATCC 1015 were evaluated at temperature $\left(25-60{ }^{\circ} \mathrm{C}\right), \mathrm{pH} 5-9$ and enzyme loading $(10-35 \%$, v/v) for optimization. The effect of inducers on lipase production was also carried out by using coconut oil, physic nut oil, groundnut oil and olive oil. A. niger ATCC 1015 gave the largest halo on the medium with $102.4 \mathrm{U} / \mathrm{g}$ activity. Zones of hydrolysis also increased with time and ranged from $3 \mathrm{~mm}$ to $10 \mathrm{~mm}$ at $30{ }^{\circ} \mathrm{C}$ for $96 \mathrm{~h}$. The ability of cells to maintain sharp contrast between green medium and its clear zone without prior replication permits direct visualization and isolation of positive strains.

Optimum production of the enzyme (specific activity $216.7 \mathrm{Umg}^{-1}$ ) was attained at temperature $45^{\circ} \mathrm{C}$, pH 7 , and enzyme loading $(25 \%$ v/v) with physic nut oil (2\%) inducer. Hence A. niger ATCC 1015 strain can be commercially exploited as a potential lipase producing strain for industrial application.

Keywords: Bromocresol green medium; solid state fermentation; optimization; Aspergillus niger ATCC 1015

\section{INTRODUCTION}

Lipase (EC 3.1.1.3) occurs widely in nature and can be produced by many microorganisms, prokaryotes and higher eukaryotes. Lipases are present in higher plants seeds, such as castor bean and canola. In these plants, they are engaged in several lipid metabolism steps, including fat digestion, adsorption, and reconstitution. They are also found in several plants' energy reserve tissues (Sharma et al., 2001; Castro et al., 2004; Freire and Castilho, 2008; Jaeger and Eggert, 2002; Villeneuve, 2003; Cavalcanti et al., 2007). Due to habitats' multiplicity, microorganisms usually produce various lipases types, with distinct specificity regarding to substrate utilization and also to optimum $\mathrm{pH}$ and temperature range. Lipases can be produced by bacteria, filamentous fungi, and yeasts, allowing these microorganisms to use lipids from animal or vegetable origin as carbon and energy sources for their growth. Though many microorganisms have been reported in literature as lipase producers, the genera Candida, Rhizopus, and Pseudomonas are considered the main industrial sources of lipases (Eastmond and Graham, 2001; FAO, 2010; Melo et al., 2006. The yeast Candida rugosa is the most employed microorganism for lipase production (Freire and Castilho, 2008).Generally, microorganisms being the preferred source for the production of industrial enzymes have the following advantages, they have high yield of conversion of substrate into product, shortest generation time, simplicity in genetic manipulation and great versatility to environmental conditions.

The interest in lipase has grown over the last few years due to their diverse industrial applications such as additives in detergents, the elaboration of dietetic foods for use in the food industry, obtaining bioactive molecules in the pharmaceutical industry and pure optical compounds in chemical synthesis processes (Kazlauskas, 1994; Mohanasrinivasan et al, 2009). Enzymes in organic media without a free aqueous phase are known to display useful unusual properties which have firmly established non aqueous enzyme systems for synthesis and biotransformations (Klibanov, 1997). Application of lipases in oleochemical processing saves energy and minimizes thermal degradation during hydrolysis, glycerolysis, acidolysis and alcoholysis (Bornscheuer, 2000) Moreover, lipases have been successfully used as catalyst for synthesis of esters (Vulfson, 1994).

The use of solid media permits a fast screening of large populations of fungi, thus allowing the detection of specific enzymes (Bruhiman et al, 1994; Thompson and Eribo, 1984; Zare-Maivan and Shearer, 1988) and helping in the chemotaxonomical differentiation of many microorganisms (Hankin and Anagnostakis, 1975). According to Cheetham (1987) the search for a new biocatalyst may require the screening of ten thousand to one hundred thousand microorganisms and an average of five to ten man years. Therefore, the emphasis on screening techniques rather than indirect or random methods should be on rational and direct screening procedures. Cheap, simple, rapid and very selective methods are of very great value. The use of lipases in industry is still limited by the cost of commercial enzymes, especially when large quantities of enzyme are required and when the final product is of low added value. There is therefore a considerable interest in reducing the cost of producing these biocatalysts.

The use of solid-state fermentation (SSF) as a production system is one way of reducing enzyme production costs, especially because agroindustrial waste can be used as a culture medium. Benjamin and Pandey (1997) cultivated Candida rugosa on coconut oil cake for lipase production using SSF and SmF systems. Enzyme yields were higher in the former. Several carbon sources-individually and in combinations were tested for their efficiency to produce lipases. Raw cake supported the growth and lipase synthesis by the yeast culture. However, supplementation with additional $\mathrm{C}$ - and $\mathrm{N}$-sources increased enzyme titers. Bhusan et al. (1994) reported lipase production in SSF system from an alkalophilic yeast strain belonging to Candida sp. Rice bran and wheat bran, oiled with different concentrations of rice bran oil were used as the substrate. Rice bran supplemented with oil gave higher lipase yields.

We have adopted an innovative isolation technique which involves the use of artificial chromogenic substrates and selective media such as Bromcresol green agar for direct isolation of lipase producers from the groundnut cake waste substrates. Moreover, modified conventional SSF medium has been used for the 
production and optimization of extracellular lipase of this screened A. niger ATCC 1015 .

\section{MATERIAL AND METHODS}

\section{Microorganisms}

The fungal strains were isolated from groundnut cake wastes. Whole cakes were kept in the open air environment and fungi growths were noticed after a week. Pure culture of fungal isolates was obtained by sub culturing onto the Sabourand Dextrose Agar (SDA) medium. It was maintained on SDA slants at $4{ }^{\circ} \mathrm{C}$.

\section{Substrates}

Rice bran, Soybean, cassava starch flour, olive oil and physic nut seeds were purchased from Itoku local market in Abeokuta South LGA,Ogun State. Physic nut and coconut oil was mechanically extracted using hydraulic pressed machine while groundnut oil was a gift from a friend in Bida, Niger State. Nigeria.

\section{Media}

Sabourand Dextrose Agar (SDA) by Oxoid Ltd. England.

\section{Reagents}

Bromocresol green dye (3',3',5',5' Tetrabromo-m-cresolfonephthalein), Tween 80 (Sigma Chemicals Ltd, USA), acetic acid, (BDH Chemicals Ltd., England). Sodium hydroxide, sodium acetate, phenolphthalein (Fluka, Switzerland). All chemicals were of analytical grade (ANALAR).

\section{Screening of lipase producing fungi}

The bromocresol green agar medium prepared according to the method of Akpan (2004). Pure culture of fungi isolated from one hundred and six (106) samples were inoculated on Bromocresol green agar medium containing Tween 80 and incubated at $30{ }^{\circ} \mathrm{C}$ for $72 \mathrm{hrs}$. Lipase positive of fungal isolates produced colour change from green to yellow around the colonies while those that give no colour change were taken to be non lipolytic microorganisms (Akpan 2004). The diameter of the yellow zones around the colonies was estimated by metre rule taking the average of two perpendicular measurements.

\section{Molecular characterization of fungi isolates}

The extraction of total genomic DNA and Polymerase Chain Reaction (PCR) using standard methods were carried out at Biotechnology Centre, Federal University of Agriculture, Abeokuta, Nigeria while the sequencing was done at Macrogen Inc. USA.

\section{Determination of enzyme activity}

The isolates were cultured on solid state fermentation (SSF) containing rice bran, physic nut, cassava and soybean flour $(5: 5: 1: 3, \mathrm{w} / \mathrm{w})$ according to the method of Osho et al., (2014a). The crude enzyme was recovered from the moldy bran as described by Mohanasrinivasan et al., (2009). The lipase activity was determined according to the modified method of Lin $\boldsymbol{e t}$ al, (2008). Vegetable oil $(8.9 \mathrm{ml})$ was treated with $1.0 \mathrm{ml}$ of crude (prepared in $0.05 \mathrm{M}$ phosphate buffer, $\mathrm{pH} 7.0$ ) and $0.1 \mathrm{ml}$ of Tween 80 was used as emulsifying agent. The reaction mixture was mixed with vortex mixer for $1 \mathrm{~min}$. It was then incubated in orbital incubator at $45^{\circ} \mathrm{C}$ for $30 \mathrm{~min}$ at $180 \mathrm{rpm}$. The reaction was stopped by adding 25 $\mathrm{ml}$ warm ethanol to $1 \mathrm{ml}$ of the hydrolysate. It was further agitated manually for 1 min and titrated with $0.1 \mathrm{~N} \mathrm{NaOH}$ until $\mathrm{pH}$ end-point 11.0 using phenolphthalein as indicator. One unit of lipase activity was defined as the amount of enzyme which produced $1 \mu \mathrm{mol}$ of fatty acids equivalent per minute under the assay conditions. The activity was established according to the following equation:

\section{N.(Vs - Vb). MM \\ $10 . \mathrm{m}$}

\author{
Where \\ $\mathrm{N}=\mathrm{NaOH}$ normality, \\ Vs $=$ volume of base used in sample titration $(\mathrm{ml})$ \\ $\mathrm{Vb}=$ volume of base used in blank titration $(\mathrm{ml})$ \\ $\mathrm{MM}=$ Molecular Mass of the predominant fatty acid $(\mathrm{g})$ \\ $\mathrm{m}=$ sample mass $(\mathrm{g})$ de Souza et al, (2010)
}

\section{Protein Determination}

The concentration of protein in the enzyme was estimated by the method of Groves et al., (1968). Protein content was determined by measuring the UV absorbance of the sample at $260 \mathrm{~nm}$ and $280 \mathrm{~nm}$. The method is based on the fact that nearly all proteins have an absorption maximum at about $280 \mathrm{~nm}$ (due mainly to tryptosine and tryptophan side chains), and a minimum near $260 \mathrm{~nm}$ whereas the reverse is true with nucleic acids. The protein concentration in sample is calculated using the following equation:

Protein concentration $\left(\mathrm{mgml}^{1}\right)=\left(1.55 \mathrm{~A}_{280}-0.76 \mathrm{~A}_{260}\right) \times$ dilution factor

Where $\mathrm{A}_{280}$ absorbance at $280 \mathrm{~nm}$

$\mathrm{A}_{260}$ absorbance at $260 \mathrm{~nm}$

Specific Activity $\left(\mathrm{Umg}^{1}\right.$ protein $)=$

Hama et al., (2007)

amount of protein

\section{Characterization of Crude Lipase}

Effect of temperature on lipase activity

The effect of temperature on lipase activity was determined at temperature range from $25-60{ }^{\circ} \mathrm{C}$. The extract was buffered with $0.05 \mathrm{M}$ phosphate buffer $(\mathrm{pH} 7)$ and vegetable oil was used as the substrate. The reaction mixture containing lipase (conc. $20 \%, \mathrm{v} / \mathrm{v}$ ) was incubated in orbital incubator for $30 \mathrm{~min}$ at $180 \mathrm{rpm}$ at each temperature. Enzyme activity was determined as described above.

\section{Effect of pH on lipase activity}

The lipase activity was evaluated at $\mathrm{pH}$ range from 5- 9 using different buffers (acetate buffer $\mathrm{pH} 5$, phosphate buffer $\mathrm{pH}$ 6-9). The enzymatic extract was buffered with $0.05 \mathrm{M}$ phosphate buffer at appropriate $\mathrm{pH}$ value and the reaction mixture containing lipase (conc. $20 \%, \mathrm{v} / \mathrm{v}$ ) and the substrate was incubated in orbital incubator for $30 \mathrm{~min}$ at $180 \mathrm{rpm}$ at $45^{\circ} \mathrm{C}$. Lipase activity was determined as described above.

\section{Effect of enzyme loading on lipase activity}

The effect of enzyme loading on lipase activity was determined by varying the lipase concentration $(10-35 \%, \mathrm{v} / \mathrm{v})$. The enzymatic extract was buffered with $0.05 \mathrm{M}$ phosphate buffer ( $\mathrm{pH}$ 6) and the reaction mixture containing lipase (at varying concentrations) and the substrate was incubated in orbital incubator for $30 \mathrm{~min}$ at $180 \mathrm{rpm}$ at $45^{\circ} \mathrm{C}$. The activity was determined as described above.

\section{Effect of different oils as inducer on lipase production}

The effect of inducers on lipase production by A. niger ATCC 1015 was also carried out by substituting the Tween 80 with coconut oil, physic nut oil, groundnut oil and olive oil. These were added separately to the solid substrates and sterilized at $121^{\circ} \mathrm{C}$ for $15 \mathrm{~min}$. The sterilized medium was allowed to cool and thereafter inoculated with $1.0 \mathrm{ml}$ of 7 day old spores suspension of A. niger ATCC 1015 and incubated at $30^{\circ} \mathrm{C}$ for $96 \mathrm{~h}$. The crude extract of fermented medium was assayed and the lipase activity and protein concentration were determined as described above.

\section{RESULTS AND DISCUSSION}

\section{Screening of lipase positive fungi}

Out of the one hundred and six (106) fungi isolated and screened on the Bromocresol green medium for lipase production, seven strains of mold and two of yeast were detected to be lipase positive. They were identified as Aspergillus niger[G-47, G- 51 (Figure 1), B- 17, B- 33]; A. oryzae [B- 05 (Figure 2)]; A niger ATCC 1015 (Figure 3); A. niger CBS 513.88 with non lipolytic mold on Bromcresol green medium (Figure 4) and Candida sp. [H- 06 (Figure 5), H- 11)] The isolated lipolytic A.niger ATCC 1015 produced an extracellular lipase and its ability to hydrolyze lipid in the medium resulted in the colour change of the surrounding medium from green to yellow thus becoming acidic due to the release of fatty acids and glycerol. This was detected by adding Bromocresol green medium as the diameter of clear zones elaborated by the strains increased with incubation time. Ogundero (1980) established the fact that the lipolytic activities of fungi increased with increase in incubation period. Differences in the ability of the lipolytic fungi to hydrolyze oil could be due to the amount of enzyme excreted into the medium and the different growth rates of the strains. 


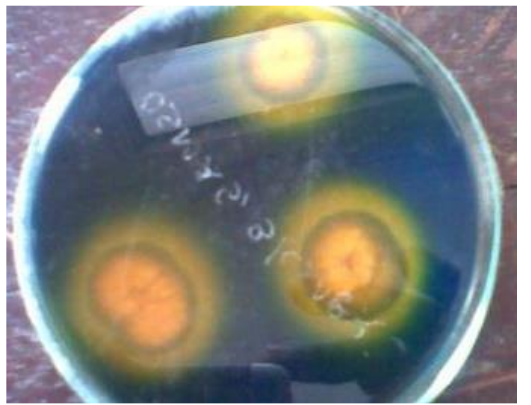

Figure 1 Lipolytic strains of Aspergillus oryzae G-51 on the medium

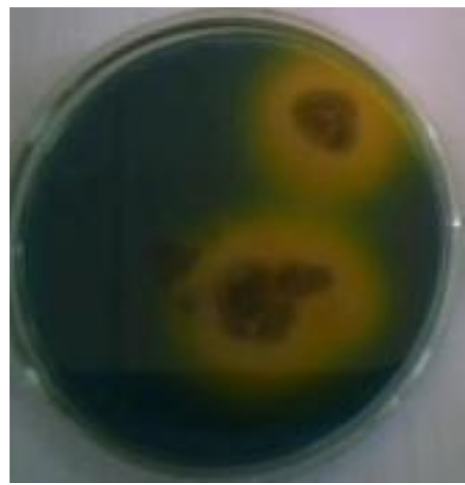

Figure 2 Lipolytic strain of Aspergillus niger B-05 on the medium

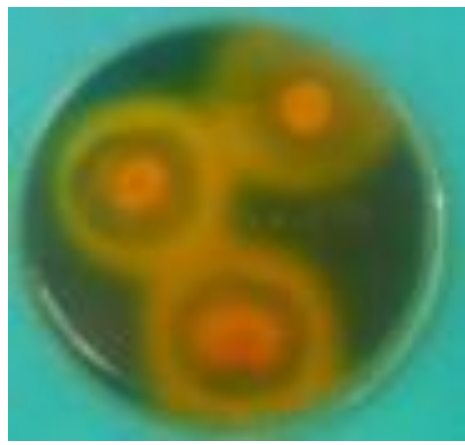

Figure 3 Lipolytic strain of Aspergillus niger ATCC 1015 on the medium

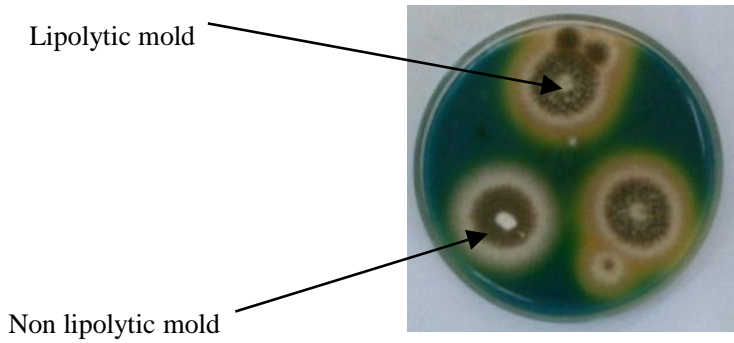

Figure 4 Lipolytic strain of Aspergillus niger CBS 513.88 and non-lipolyitc mold on the medium

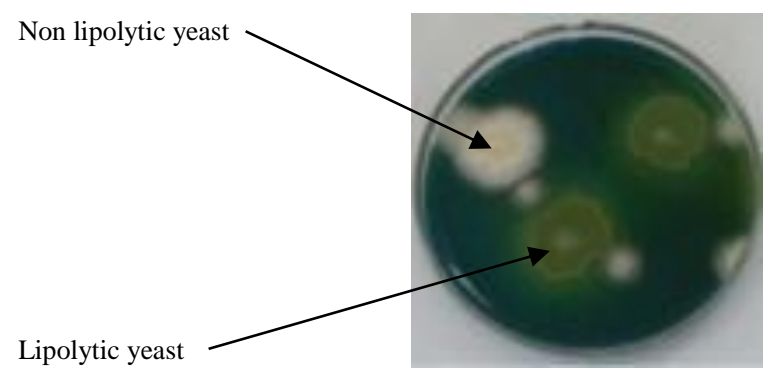

Figure 5 Lipolytic strain of Candida sp. H-06 and non lipolytic mold on the medium
Lipase production with zone of inhibition by various strains of microorganisms isolated on the substrate

Table 1 shows lipase production by strains of Aspergillus niger and A. oryzae A.niger CBS 513.88 gave lipase activity of $52.7 \mathrm{Ug}^{-1}$ with $5 \mathrm{~mm}$ diameter of yellow zone around the colonies at $72 \mathrm{~h}$ incubation time among the isolated species while $A$. oryzae G- 51 had $34.8 \mathrm{Ug}^{-1}$ with $4 \mathrm{~mm}$ width of clear zone at 96 $\mathrm{h}$ incubation time. A. niger ATCC 1015 (Figure 3) gave the highest lipase activity of $102.4 \mathrm{Ug}^{-1}$ with $10 \mathrm{~mm}$ width of clear zone at $96 \mathrm{~h}$ incubation time which is 2.94-fold increase compared with the A. orzyae $G-51$. The lipase producing Candida sp. strains $\mathrm{H}-06$ had lipase activity of $15.3 \mathrm{Ug}^{-1}$ with $3 \mathrm{~mm}$ width of clear zone at $96 \mathrm{~h}$ incubation time as compared with its counterpart strain $\mathrm{H}-11$ with $14.4 \mathrm{Ug}^{-1}$ and $4 \mathrm{~mm}$ diameter of yellow zone around the colonies at the same incubation time (Table 2). The lipolytic activity demonstrated by A. niger ATCC 1015 was 6.7 times higher than the best yeast strain. Figure 5 showed Candida sp. H- 06 with non lipolytic white colony. In all isolates, the diameter of clear zones elaborated by the strains increased with incubation time. Loss of activity on the fourth day of incubation may be attributed to the deactivation of the enzymeas a result of slight acidic medium (not reported). This result support the findings of Osho et al., (2014b) when extracellular lipase was synthesized from a rice-bran physic nut cake waste as solid substrates. Lipases have been produced from different microorganisms using SSF with different solid wastes, such as lipase from Penicillium restrictum in babassu cake (Azeredo et al. 2007); lipase from Candida rugosa in rice flour (Rao et al., 1993). These lipases were produced by SSF on a bench scale, mostly using tray bioreactors, and yielded high productivity rates.

$\underline{\text { Table } 1 \text { Lipase production by Aspergillus niger and A.oryzae strains }}$

StrainsWidth of clear zones $(\mathrm{mm})^{\circ}$

$$
24 \mathrm{~h} \quad 48 \mathrm{~h} \quad 72 \mathrm{~h} \quad 96 \mathrm{~h}
$$

Lipase activity $\left(\mathrm{Ug}^{-1}\right)^{*}$

\begin{tabular}{|c|c|c|c|c|c|}
\hline A.nigerCBS 513.88 & 2 & 4 & 5 & 5 & $52.7 \pm 0.83$ \\
\hline A.niger $\mathrm{B}-17$ & 1 & 3 & 4 & 5 & $24.4 \pm 0.64$ \\
\hline A.niger B- 33 & 1 & 2 & 2 & 4 & $15.3 \pm 0.12$ \\
\hline A.nigerATCC 1015 & 3 & 6 & 8 & 10 & $102.4 \pm 0.91$ \\
\hline A.niger B-05 & 2 & 4 & 6 & 7 & $43.6 \pm 0.16$ \\
\hline A.oryzaeG- 47 & 2 & 3 & 3 & 4 & $22.7 \pm 0.67$ \\
\hline A.oryzaeG- 51 & 2 & 3 & 4 & 4 & $34.8 \pm 0.22$ \\
\hline
\end{tabular}

*Mean of triplicate \pm standard deviation

${ }^{\circ}$ Zone of hydrolysis is the average of two perpendicular measurements

Table 2 Lipase production by Candida sp. strains

\begin{tabular}{ccccccc} 
Strains & \multicolumn{4}{c}{ Width of clear zones $(\mathrm{mm})^{\circ}$} & & Lipase activity $\left(\mathrm{Ug}^{-1}\right)^{*}$ \\
& $24 \mathrm{~h}$ & $48 \mathrm{~h}$ & $72 \mathrm{~h}$ & $96 \mathrm{~h}$ & \\
\hline Candida sp. H-06 & 1 & 2 & 2 & 3 & $15.3 \pm 0.33$ \\
Candida sp. H-11 & 1 & 2 & 3 & 4 & $14.4 \pm 0.14$ \\
\hline
\end{tabular}

* Mean of triplicate \pm standard deviation

${ }^{\circ}$ Zone of hydrolysis is the average of two perpendicular measurements

\section{Characterization of crude lipase of A. niger ATCC1015}

\section{Effect of assay temperature on lipase activity}

The effect of assay temperature on lipase activity of the crude enzyme is presented in Figure 6(a). Temperature had great influence on the activity of the enzyme. As the temperature increases the activity increases with optimum activity of $156.7 \mathrm{Ug}^{-1}$ at $45^{\circ} \mathrm{C}$ and decreased drastically at temperatures above 60 ${ }^{\circ} \mathrm{C}$. The basis for stability of lipase at relatively high temperature might be linked to the fact that the lipases are highly hydrophobic (Pandey and Benjamin, 2001). The hydrophobic amino acids are concentrated near the catalytic center with the non-polar surface around the active site greatly expanding thus the amino-acids found on the side of the 'lid' that overarching the catalytic site (SerHis-Glu) become completely exposed (Gordillo et al., 1995). However, Adebiyi 
et al., (2003) attributed the thermostability properties of the lipase to the presence of allosteric inhibitors which protect the enzyme against heat inactivation. Similarly, lipases from A. niger strains have been reported to be active between 40 and $55{ }^{\circ} \mathrm{C}$ (Kamini et al, 1998; Namboodiri et al., 2000; Falony et al. 2006).

\section{Effect of assay pH on lipase activity}

The result of $\mathrm{pH}$ studies as shown in Figure 6(b) indicated that the crude lipase extract was most active at $\mathrm{pH} 7$ with optimal activity of $127.7 \mathrm{Ug}^{-1}$. However, it could also exhibit activeness in slightly alkaline medium. Crueger and Cruegger (1993) and Falony et al., (2006) obtained similar result for a lipase expressed by another $A$. niger strain. The gradual $\mathrm{pH}$ increase was probably caused by the release of proteases resulting in deamination of amino acids and liberation of ammonia (Gombart et al., 1999). However, the stability studies of Candida rugosa lipase conducted by Pandey and Benjamin (2001), focused mainly on the conformational changes caused by the $\mathrm{pH}$ changes. That change might reduce or impose strain on the 'lid' overarching the active center, thereby open or shut down the catalytic center for substrate binding.

\section{Effect of enzyme loading on lipase activity}

The effect of enzyme loading on the lipase activity the enzyme is presented in Figure 6(c). The enzyme loading between the ranges $20-30 \%$ weight of oil substrate slightly increases the production of lipase. Thus enzyme loading had an insignificant effect on lipase production $(\mathrm{P} \leq 0.05)$. The optimal loading of $25 \%$ $(\mathrm{w} / \mathrm{v})$ gave the maximum activity of $136.9 \mathrm{Ug}^{-1}$ which retained about $75 \%$ of its initial activity at $30{ }^{\circ} \mathrm{C}$. Similar results have been reported for other fungal lipases by Mozaffar and Weete (1993) and Phillips and Pretorius (1991).

\section{The effect of different vegetable oils on lipase production}

The effect of inducers on lipase production is shown in Figure 7. The substitution with physic nut oil significantly increases lipase production with specific activity at $216.7 \mathrm{Umg}^{-1}$ while groundnut, coconut and olive oil is157.6 $\mathrm{Umg}^{-1}, 86.8 \mathrm{Umg}^{-}$ ${ }^{1}$ and $64.7 \mathrm{Umg}^{-1}$ respectively.Analysis of variance showed that the influence of these vegetable oils used as inducers is significant at $5 \%$ level. The findings on the effect of inducers on lipase production which revealed that physic nut oil (2 $\%$ ) has the highest enzyme specific activity can be established by the result of Rao et al. (1993) that verified that oil content was a significant variable affecting the yield. Ban et al. (2001) also in their work concluded that oil acted as carbon source as well as inducers for lipase production. Extracellular lipase production by different microorganisms on lipids has been extensively reported (Nutan et al., 2002).

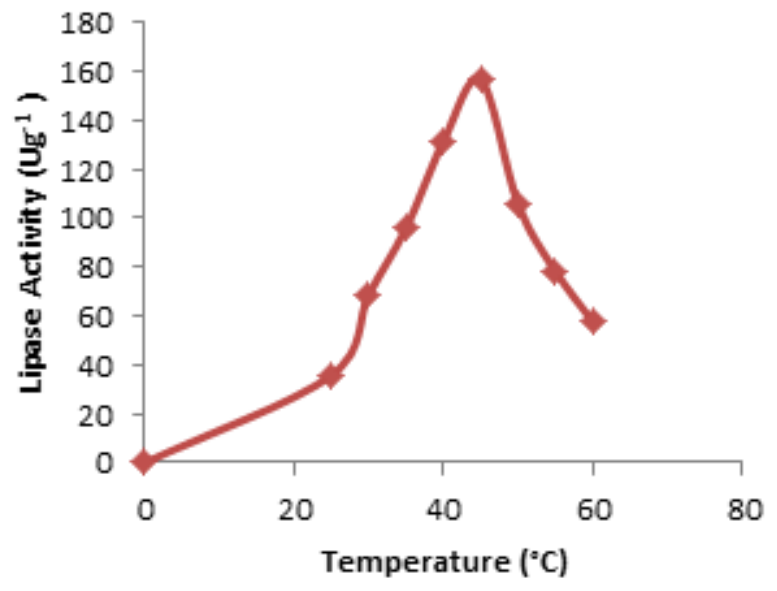

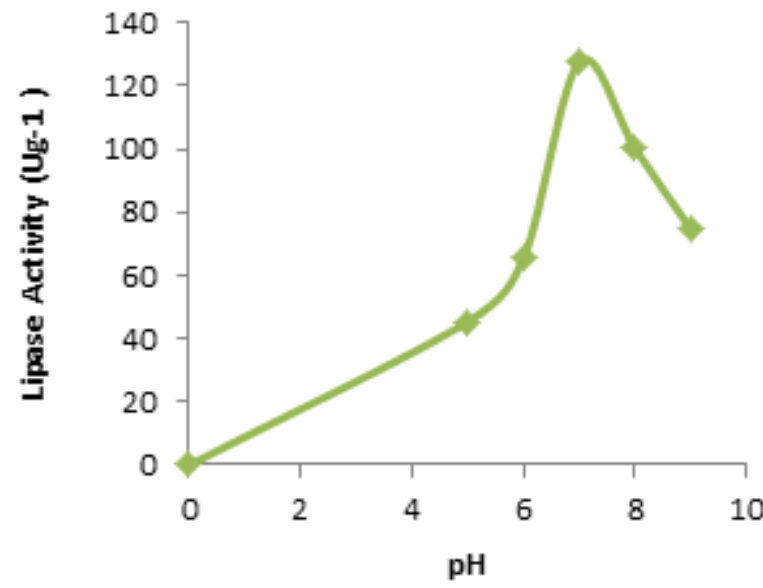

(a)

(b)

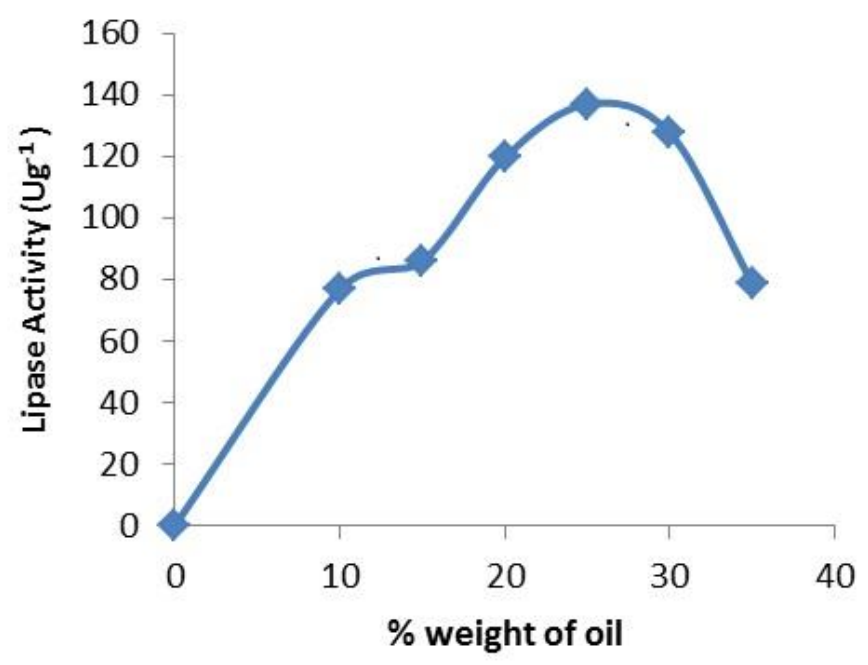

(c)

Figure 6 Effect of assay temperature (a); pH (b) and enzyme activity (c) on lipase activity of $A$. niger ATCC 1015

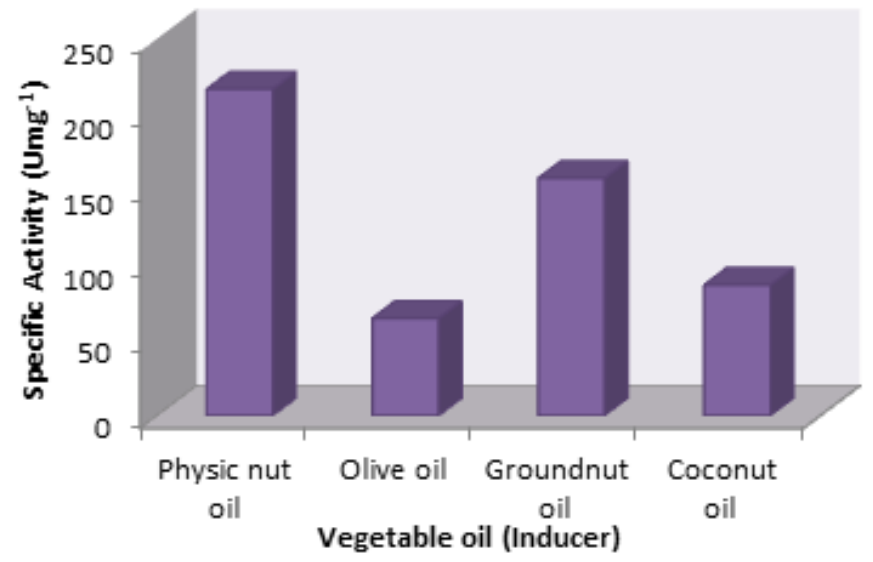

Figure 7 Effect of different vegetable oils as on lipase production

\section{CONCLUSION}

This extracellular lipase from strain A.niger ATCC 1015 is of industrial and commercial interest and can be synthesized by simple screening in a chromogenic substrate without necessarily interfering cell intact with maximum 
productivity. Increase in temperature increases the activity with optimum 156.7 $\mathrm{Ug}^{-1}$ at $45^{\circ} \mathrm{C}$. The lipase extract was most active at $\mathrm{pH} 7$ with optimal activity of $127.7 \mathrm{Ug}^{-1}$ and enzyme loading between 20 - $30 \%$ weights of oil substrate slightly increases the production with maximum activity of $136.9 \mathrm{Ug}^{-1}$ which is about 75 $\%$ of its initial activity. The inducer substitution with physic nut oil significantly increases lipase production with specific activity of $216.7 \mathrm{Umg}^{-1}$.

Acknowledgement: The authors express appreciation to the technical staff of Biotechnology Centre, Federal University of Agriculture, Abeokuta, Nigeria for the extraction of DNA and PCR procedures.

\section{REFERENCES}

ADEBIYI, A.O., AKINBORO, A. AND OLOKE, J.K. 2003.Characterization of thermostable lipase from local isolate of Trichoderma viride. Science Focus 3, 49-53.

AKPAN, I. 2004. Screening for novel fungal biocatalysts. Nigerian Journal of Microbiology 18: 288-292.

AZEREDO, L. A. I., GOMES, P. M., SANT’ANNA JR. G. L. CASTILHO, L. R. AND FREIRE D.M.G. 2007. Production and regulation of lipase activity from Penicillium restrictum in submerged and solid-state fermentations. Curren Microbiology 54 (5) 361-365 http://dx.doi.org.10.1007/s00284-006-0425-7

BAN, K., KAIEDA, M., MATSUMOTO, T., KONDO, A. AND FUKUDA, H 2001. Whole cell biocatalyst for biodiesel fuel production utilizing Rhizopus oryzae cells immobilized within biomass support particles. Biochemica Engineering 8:39-43 http://dx.doi.org.10.1016/S1369-703X(00)00133-9 BENJAMIN, S. AND PANDEY, A. 1997.Enhancement of lipase production during repeated batch cultivation using immobilised Candida rugosa. Proces Biochemistry 32: 437- 440 http://dx.doi.org.10.1016/S0032-9592(96)00102-1 BHUSAN, B., DOSANJIH, N. S., KUMAR, K. AND HOONDAL, G. S. 1994 Lipase production from an alkalophilic yeast sp. by solid state fermentation. Biotechnology Letter 16: 841-842 http://dx.doi.org.10.1007/BF00133964

BORNSCHEUER, U.T.2000. Enzymes in lipid modificationWeinheim, editor, Wiley-VCH, 2000 http://dx.doi.org/10.1002/3527606033

BRUHIMANN, F., KIM, K S, ZIMMERMAN, W. AND FIECHTER. A. 1994 Pectinolytic enzymes from Actinomyces for the degumming of ramiebast fibers. Applied and EnvironmentalMicrobiology 60: 2107-2112.

CASTRO, H. F., MENDES, A.A. AND SANTOS, J.C. 2004.Modificac, aode 'ao,imicaNova, vol. oleosegorduraspor biotransformac, Qu'27, (1) 146-156.

CAVALCANTI, E.D.C., MACIEL, F.M., VILLENEUVE, P. LAGO, R.C.A MACHADO, O. L.T. AND FREIRE, D. M. G. 2007. Acetone powder from dormant seeds of Ricinus communis L: lipase activity and presence of toxic and allergenic compounds. Applied Biochemistry and Biotechnology. 137-140 (1-12) 57-65 http://dx.doi.org.10.1007/s12010-007-9039-1

CHEETHAM, P.S.J. 1987. Screening for novel biocatalysts. Enzyme Microbial Technology 9: 197-212 http://dx.doi.org.10.1016/0141-0229(87)90016-0 CRUEGER, W. AND CRUEGER, A. 1993. Biotechnology: Industrial Microbiology Manual, S.A. Acribia (Ed.), Zaragoza, Spain233-234. de SOUZA, J. S., CAVALCANTI-OLIVERA, E. D., ARANDA, D.A.G. AND FREIRE, D.M.G. 2010. Application of lipase from the physic nut (Jatropha curcas L.) to a new hybrid (enzyme/chemical) hydroesterification process for biodiesel production. Journal of Molecular Catalysis B:Enzymatic 65: 133-137 http://dx.doi.org .10.1016/j.molcatb.2010.01.003

EASTMOND, P. J. AND GRAHAM, I.A. 2001. Re-examining the role of the glyoxylate cycle in oil seeds. Trends in Plant Science.6 (2) 72-77 http://dx.doi.org.10.1016/s1360-1385(00)01835-5.

FALONY, G., ARMAS J.C., DUSTET MENDOZA J.C. AND MARTÍNEZ HERNÁNDEZ J. L. 2006. Production of Extracellular Lipase from Aspergillusnigerby Solid-State Fermentation. Food Technology Biotechnology 44 (2): 235-240.

FOOD AND AGRICULTURE ORGANIZATION OF THE UNITED NATIONS (FAO), 2010.Food Outlook, FAO, New York, NY, USA.

FREIRE, D.M.G. AND CASTILHO, L.R. 2008. Lipase semBiocat'alise,inEnzimasemBiotecnologia.Produc, , , ao, AplicacoeseMercado. Interci^encia, RiodeJaneiro,Brazil. (1), 369-385.

GOMBART, A.K.; PINTO, A.I.; CASTILlO, L.R. AND FRIERE, D.M.G. 1999.Lipase production by Penicillium restricumin solid state fermentation using babassu cake as substrate. Process Biochemistry 35:85-90 http://dx.doi.org.10.1016/S0032-9592(99)00036-9

GORDILLO, M. A., OBRADORS, N., MONTESINOS, J. L.,VALERO, F. LAFUENTE, J. AND SOLA, C. 1995. Stability studies and effect of initial oleic acid concentration on lipase production by Candida rugosa. Applied Microbiology Biotechnology $\quad 43: \quad 38-41$ http://dx.doi.org.10.1007/s002530050367

GROVES, W.E., DAVIS JR., AND SELLS, B.H. 1968. Analytical Biochemistry 22: 195. In Deutscher, Murray, P. Methods in Enzymology: Guide to Protein Purification. Academic Press Inc. 182: 55

HAMA, S., YAMAJI, H., FUKUMIZU, T., TAMALAMPUDI, S., KONDO, A., NODA, H. AND FUKUDA, H. 2007. Biodiesel-fuel production in a packed-bed reactor using lipase-producing Rhizopus oryzae cells immobilized within biomass support particles. Biochemical Engineering 34: 273-278 http://dx.doi.org.10.1016/j.bej.2006.12.013

HANKIN, L. AND ANAGNOSTAKIS, R. F. 1975. The use of solid media for detection of enzyme production by fungi. Mycology 67: 597-606.

JAEGER, K. E. AND EGGERT, T. 2002. Lipases for biotechnology. Current Opinion in Biotechnology. 13 (4) 390-397 http://dx.doi.org 10.1016/S0958 1669(02)00341-5

KAMINI, N.R., MALA, J.G.S. AND PUVANAKRISHNAN, R. 1998. Lipase production from Aspergillus niger by solid state fermentation using gingelly oil cake, Process Biochemistry 33:505-511 http://dx.doi.org.10.1016/S00329592(98)00005-3

KAZLAUSKAS, R. 1994. Elucidating structure mechanism relationship in lipases, prospects for predicting and engineering catalytic properties.Trends In Biotechnology 12(11):464-472 http://dx.doi.org.10.1016/0167-7799(94)90022

KLIBANOV, A.M. 1997. Why are enzymes less active in organic solvents than in water? Trends InBiotechnology15 (3)97-101 http://dx.doi.org.10.1016/S0167-7799(97)01013-5

LIN, H. H., OO, W.N.N., THU, M. K. AND OO, M. M. 2008. Screening of lipase producing yeast for lipase catalyzed transesterification of vegetables oils GMSARN International Conference on sustainable Development: Issues and Prospects for the GMS.

MELO,J.C. TEIXEIRA, J.C., BRITO, J.A., PACHECO, J.G.A. AND STRAGEVITCH, L.2006. Produc, Oleo de Oiticica," in ao de Biodiesel de Proceedings of the ICongressodaRedeBrasileirade Tecnologia do Biodiesel. 164169

MOHANASRINIVASAN, V., DHRISYA, P., DIPINSHA, K. P., MANU, U. C. MEGHA, V. K. AND SUBATHRA, D. C.2009. A comparative study of the lipase yield by solid state and submerged fermentation using fungal species from biopharmaceutical oil waste. African Journal of Biotechnology8 (1) 73-75 http://dx.doi.org.10.5897/AJB2009.000-9013

MOZAFFAR, Z. AND WEETE, J.D. 1993. Purification and properties of an extracellular lipase from Pythium ultimum, Lipids, 28 (5):377-392 http://dx.doi.org.10.1007/BF02535933

NAMBOODIRI, V.M., HARIDASAN, C. AND CHATTOPADHYAYA, R. 2000. Purification and biochemical characterization of a novel thermostable lipase from Aspergillus niger, Lipids35:495-502 http://dx.doi.org.10.1007/s11745-000-549-3

NUTAN, D., ULKA, S.P., BASTAWDE, K.B., KHIRE, J.M. AND GOKHALE, D.V. 2002. Production of acidic lipase by Aspergillus niger in solid state fermentation, Process Biochemistry http://dx.doi.org.10.1016/S0032-9592(02)00194-2

OGUNDERO, V. W.1980.Lipase activity of thermophilic fungi from mouldy $\begin{array}{lllll}\text { groundnuts in } & \text { Nigeria. Mycologia } & & \end{array}$ http://dx.doi.org/10.2307/3759424

OSHO, M. B., POPOOLA, T.O.S., KAREEM, S. O. AND AROWOLO, T. A 2014a. Transesterification of Jatropha seeds oil by vegetative spongeimmobilized lipase of Alternaria sp. MGGP 06 for fatty acid methyl ester production under optimized conditions. Petroleum Technology Development Journal 4 (1) 57-70.

OSHO, M.B., POPOOLA, T.O.S. AND KAREEM, S.O. 2014b. Immobilization of Aspergillus niger ATCC 1015on bionatural structures for lipase production. Engineering In Life Science $s \quad$ 14: 449-454 http://dx.doi.org.10.1002/elsc.201300129

PANDEY, A. AND BENJAMIN, S. 2001. Isolation and characterization of three distinct forms of lipases from Candida rugosa produced in solid state fermentation. Brazillian Archives of Biology and Technology 44(2)213-221.

PHILLIPS, A. AND PRETORIUS, G. H. J. 1991. Purification and characterization of an extracellular lipase of Galactomyces geotrichum Biotechnology Letters 13: 833-838 http://dx.doi.org.10.1007/BF01026769

RAO, P.V., JAYARAMAN, K. AND LAKSHMANAN, C.M. 1993. Production of lipase by Candida rugosa in solid state fermentation. 1: Determination of significant process variables. Process Biochemistry 28:385-389 http://dx.doi.org.10.1016/0032-9592(93)80025-C

SHARMA, R., CHISTI, T. AND BANERJEE, U. C. 2001.Production, purification, characterization, and applications of lipases. Biotechnology Advances 19 (8) 627-662 http://dx.doi.org.10.1016/S0734-9750(01)00086-6

THOMPSON, D. P. AND ERIBO, B. E. 1984. Extracellular enzyme production by Rhizopus and Mucor species on solid media. Canadian Journal of Microbiology 30: (1) 126-128 http://dx.doi.org.10.11.39/m84-020

VILLENEUVE, P.2003. Plant lipases and their applications in oils and fats modification. European Journal of Lipid Science and Technology 105 (6)308317 http://dx.doi.org.10.1002/ejlt.200390061

VULFSON, E. N. 1997. Industrial applications of lipases. In: Woolley P Peterson SB, editors. Lipases - their structure, biochemistry and applications. Cambridge: Cambridge Univ. Press, 271-288.

ZARE, M. AND SHEARER, C. A.1988.Extracellular enzyme production and cell wall degradation by freshwater lignicolous fungi. Mycology 80: 365-375 